\title{
THE RELATION BETWEEN EMPLOYEE CHARACTERISTICS AND KNOWLEDGE SHARING
}

\author{
Jana Matoškováa* ${ }^{*}$ Ottó Bartók $k^{a}$, Lucie Tomancováa \\ ${ }^{a}$ Faculty of Management and Economics, Tomas Bata University in Zlín, Czech Republic
}

\begin{abstract}
Purpose - Knowledge sharing becomes crucial in today's competitive world to foster organizational performance. The study aim was to explore which employee characteristics facilitate knowledge sharing in the organizations and to examine the dimensions of these characteristics.

Design/methodology/approach - Opinion-based questionnaires among employees in Czech companies were applied. The research design in this study was cross-sectional. The hypotheses were tested by Pearson's correlations and regression analyses.

Findings - The findings support the idea that specific individual employee characteristics increase knowledge sharing in the organization. Four categories of potentially appropriate employee individual characteristics were suggested: 1) social and communication skills, 2) positive work feelings, 3) competences for problem-solving, and 4) employee's self-efficacy. However, only employee's positive work feelings and self-efficacy significantly predicted the extent of knowledge sharing in the organization.

Practical implications - The findings offer a basis for future research. The results of the study can be used in recruiting new employees and, managerial decision-making. The recruitment methods and the selection methods deployed should enable the firm to attract those whose values are in harmony with the organization's values. Managers should build a work environment that promotes greater and more trusting ties among employees via organizing
\end{abstract}


social activities for employees, a supervisor's acceptance of an employee's autonomy and responsibility and increasing employees' confidence in their abilities.

Originality/value - This is one of the first studies to investigate dimensions of employee knowledge-oriented characteristics. It supports the idea that some individual employee characteristics boost spontaneous knowledge sharing behaviour.

\section{Keywords:}

knowledge sharing; employee; skills; feelings; traits; self-efficacy; Czech Republic 


\section{INTRODUCTION}

In a complex, knowledge-based and turbulent economy, it is harder and harder for many companies to gain and sustain their competitive advantages. As a current critical component of competitive advantage is knowledge (Wright et al., 2001), numerous studies (e.g. Peng, 2013) recommend developing systematic processes to create and leverage knowledge - it means to implement knowledge management. The importance of knowledge management is no longer restricted to knowledge-intensive firms in high-tech industries (Teng and Song, 2011). As demonstrated by Zack (2003), even companies in traditional industries, such as cement, can benefit significantly from knowledge management.

One of the most critical processes in knowledge management is knowledge sharing. Employee knowledge will contribute little to the firm if it is not widely shared among the organizational members (Fong et al., 2011). Knowledge sharing has become vital because organizations are increasingly assigning complex decision-making (Mesmer-Magnus and DeChurch, 2009). Knowledge sharing brings numerous benefits - higher quality of an organization's performance (Kuo et al., 2014; Law and Ngai, 2008), better problem-solving (Kuo et al., 2014), and reducing costs (Peet, 2012). Thanks to knowledge sharing, the organization can understand better the consumer's needs (Lasalewo et al., 2016).

Knowledge sharing is a complex social process ( $\mathrm{Gu}$ and $\mathrm{Gu}, 2010)$ influenced by such factors as organizational culture, management support, rewards and incentives, and interpersonal trust (Peng, 2013). Many of these factors, especially trust, culture, and the role of management, were broadly examined. However, there is still not enough empirical studies dealing with the importance of individual employee characteristics.

Built on the existing research on the subject, this study attempts to enhance the understanding of the relationship between knowledge sharing and individual employee characteristics. Some individual characteristics are in previous studies recommended like those which are suitable to 
be developed in employees, but there is usually a lack of empirical evidence. Additionally, many other studies took into account only specific individual characteristics, such as adaptive behaviour (e.g. Hasgall and Shoham, 2008; Yi, 2009), ignorance (e.g. Israilidis et al., 2015), conscientiousness (e.g. Matzler et al., 2008) or outcome expectations (e.g. Hsu, Wu, et al., 2007). Thus, this study aims to explore the dimensionality of employee characteristics that are mentioned in previous studies as boosting knowledge sharing in organizations. For this purpose, a specific inventory for knowledge-oriented employee characteristics is suggested. Moreover, relations between identified specific dimensions and knowledge sharing are examined.

The remaining sections of this paper are arranged as follows. First, theoretical framing is set. Next, the research methods are described and research results follow. Results are then discussed. A consideration of the research limitations of the study and recommendations for future research are provided in the last section.

\section{THEORETICAL FRAMING AND HYPOTHESES}

\subsection{Knowledge sharing}

Knowledge sharing means that an individual shares work-relevant experiences and information with another organizational member (Lin, 2007a). Wilson (2010) adds that the phrases "information sharing", "knowledge sharing", "information exchange" can be seen as synonyms, because in none of these cases is "knowledge" shared, rather, information about what one knows is shared with another and the recipient then constructs own knowledge of a phenomenon or situation.

Knowledge sharing is a crucial contributor to the sustainability of organizational success and competitive advantage (Donnelly, 2018; Shi et al., 2020). Many researchers and practitioners, e. g. Amin, Hassan, Ariffin, and Rehman (2009) and Moser (2017), consider knowledge sharing as positively related to the performance of the organization by increasing the organization's 
resources and reducing the time wasted in trial and error. Additionally, sharing knowledge might have personal benefits for employees as well, such as pride, increased personal identification with co-workers or the organization, more respect from others, a better reputation, and reduced alienation or stronger feelings of commitment (Constant et al., 1994). Moreover, the sharing of what employees possess can make them feel needed, wanted and appreciated (Peng, 2013). With their participation in knowledge exchange, employees could also demonstrate their interest in the community and their pro-social behaviour (McLure Wasko and Faraj, 2000).

\subsection{Significance of individual characteristics}

The intensity of knowledge sharing depends highly on people who are members of the organizations. Many authors, e.g. Desouza (2003), Jarvenpaa and Staples (2001), point out that knowledge sharing is above and beyond behaviours prescribed by job descriptions and is voluntary in nature. It requires spontaneity, initiative and willingness to share from employees (Jacobs and Roodt, 2007; King, 2007; Srivastava et al., 2006). To acquire or create new knowledge, employees often have invested much effort and time into the process (Peng, 2013), which can decrease employee willingness to share their knowledge.

As people are different, employees' willingness to share knowledge might be various too. Some studies, e.g. Brčić and Mihelič (2015), Saide et al. (2016), Zheng (2017), highlight a relationship between a willingness to share knowledge and some individual characteristics. However, there is still little empirical evidence which employee individual characteristics are crucial for knowledge sharing behaviour. Thus, this paper proposes that specific employee characteristics can influence knowledge sharing.

$H_{1}$ : There is a significant positive association between selected employee individual characteristics and the extent of knowledge sharing in the organization.

\subsection{Importance of person-organization fit}


Several studies, e.g. Afsar (2016), Wahyudi et al. (2019), Wuryaningrat et al. (2019), show the importance of person-organization fit concerning knowledge sharing behaviour. Personorganization fit is generally defined as compatibility between employees and their organizations (Afsar, 2016). If employees are compatible with the set values of the company, then their tendency to share knowledge is higher (Rungsithong and Meyer, 2020). That is why many organizations have to value knowledge sharing and have employees who are aligned with those values (Audretsch et al., 2020).

There are several ways how to increase staff alignment to knowledge sharing values. The willingness of employees to share knowledge can be affected during the recruitment process by appropriately set pro-knowledge criteria (van den Berg et al., 2020). The recruitment methods and the selection methods deployed should enable the firm to attract those who like organization's values, who will be proud to work for the company at the given work position. Also, employees could be encouraged to share their knowledge by courses, training or education (Brouwer and Jansen, 2019), or by suitable organizational culture (Connelly and Kelloway, 2003).

\subsection{Knowledge-oriented employee characteristics}

If an organization wants to increase the intensity of knowledge sharing and is aware that person-organization fit is important, several interesting questions appear. One of them is on which specific characteristics of candidates or current employees to concentrate to achieve high spontaneous knowledge sharing behaviour. People differ in many aspects, like their personality traits, skills, abilities, knowledge, emotions, attitudes, and beliefs. All of them could have an impact on employee willingness to share.

First, knowledge sharing might be influenced by employee personality traits - relatively enduring styles of thinking, feeling, and acting (McCrae and Costa, 1997). According to Boateng, Dzandu, and Tang (2016) self-esteem is a trait that influences knowledge 
sharing. Employees with high organization-based self-esteem will put their efforts into those behaviours that will benefit their organizations (Peng, 2013). According to Hsu, Wu and Yeh (2007) people with a more stable personality share more knowledge. Also, flexibility might enhance knowledge sharing (Ulhøi and Stjernholm Madsen, 2005) and an employee who is more inclined towards new experiences in life might share their knowledge to gain new knowledge in return (Blau, 1964; Cabrera et al., 2006). Cabrera, Collins and Salgado (2006) suppose that the inclination of an individual to share knowledge with others is related to the degree of responsibility that is felt by the individual for work. Highly responsible employees may search for more efficient ways to do their job and one way to do so is to share knowledge with others (Á. Cabrera et al., 2006). Similarly, Gupta (2008) claim that conscientiousness has a positive relationship with knowledge sharing behaviour. People who are sympathetic, goodnatured, prosocial and cooperative are more likely willing to share their knowledge (Matschke et al., 2014; Moser, 2017; Rehman et al., 2014; Wu, 2013). Thus, highly relationship-oriented employees tend to knowledge sharing (Liebowitz and Yan, 2004), but introverts might share less knowledge (Rehman et al., 2014).

Another important category of individual characteristics related to knowledge sharing is emotions, feelings, and attitudes. Numerous researchers, e.g. Wang, Su, and Hsieh (2011), Rahman, Osman-Gani, Momen, and Islam (2015), point out trust as an essential ingredient to knowledge sharing happens. Knowledge sharing will be positively affected when an individual trust that this behaviour will be reciprocated with some benefits in the future (Cabrera and Cabrera, 2005). People must also trust that others do not misuse their knowledge (Riege, 2005), have feelings of safety (Cabrera and Cabrera, 2005) and perceived support (Cabrera and Cabrera, 2005; Chen et al., 2012; Chiang et al., 2011). Employees must not fear that their career development is in danger if knowledge sharing leads to mistakes and failures (Jacobs and Roodt, 2007). Additionally, an intense fear of the loss of knowledge advantage can hinder 
knowledge sharing behaviour (Matschke et al., 2014; Wilson, 2010). On the other hand, Kubo et al. (2001) point out that job security connected with lifetime employment practice enhances knowledge sharing. In terms of perceived support, Kim and Ko (2014) state that if employees receive favourable treatment from their organization or managers, they tend to feel obligated to reciprocate by adopting a more positive attitude toward them. Similarly, Jackson, DeNisi, and Hitt (2003) highlight that employees will be more willing to share their ideas in safe and nonjudgemental organizational climates. Regarding knowledge sharing, identification with a group and commitment are important as well. When the staff has a higher affective and normative commitment it may lead to knowledge sharing among the staff (Lin and Joe, 2012; Rahman et al., 2015). Lin (2007) adds that individuals who have a feeling of emotional attachment to their organization are likely to share their knowledge whenever they realize that to do so is in their environment appreciated and where their knowledge is used. An example of employee beliefs that are vital for knowledge sharing is self-efficacy (Cabrera et al., 2006; Lin, 2007a). Individuals with confidence in their abilities and utility of their information are likely to provide and share relevant knowledge about job-related problems (Cabrera and Cabrera, 2005; HsiuFen Lin, 2007; Kankanhalli and Tan, 2004).

According to Obermayer-Kovács, Komlósi, Szenteleki, and Tóth (2015) skills and expertise have also impact on knowledge sharing behaviour. Knowledge sharing requires an awareness of the information and knowledge needs of others and the ability to share this with others (Smith, 2017). Certain communication skills, according to Riege (2005) and Cabrera and Cabrera (2005), have been found to facilitate cooperation in knowledge exchange situations. The knowledge provider must be able to adjust form and speed when sharing knowledge and to link it to the particular recipient's previous knowledge (Cabrera and Cabrera, 2005). Similarly, Rahman, Osman-Gani, Momen, and Islam (2015) found a relationship between leadership style and knowledge sharing effectiveness where communication and 
listening skills applied a crucial mediation variance between these variables. Other desirable skills are teamwork skills (Cabrera and Cabrera, 2005). Moreover, the intentions of knowledge sharing are also increased if people are capable to use information and communication technologies (Chen et al., 2012; Gagné, 2009).

Employee individual characteristics that boost employee spontaneous tendency to knowledge sharing behaviour could be called as knowledge-oriented employee characteristics. The study of Memon et al. (2020) shows that individual differences may be multidimensional. Therefore, it can be supposed that knowledge-oriented employee characteristics are not a unidimensional construct as well. So, a dimensionality of knowledge-oriented employee characteristics and relations between identified specific dimensions to knowledge sharing are examined in this study. Additionally, a collective effect of these dimensions on the extent of knowledge-sharing is supposed. Thus,

$\mathrm{H}_{2}$ : Identified dimensions of employee knowledge-oriented characteristics have a positive collective effect on the extent of knowledge sharing in the organization.

Figure 1: Conceptual framework

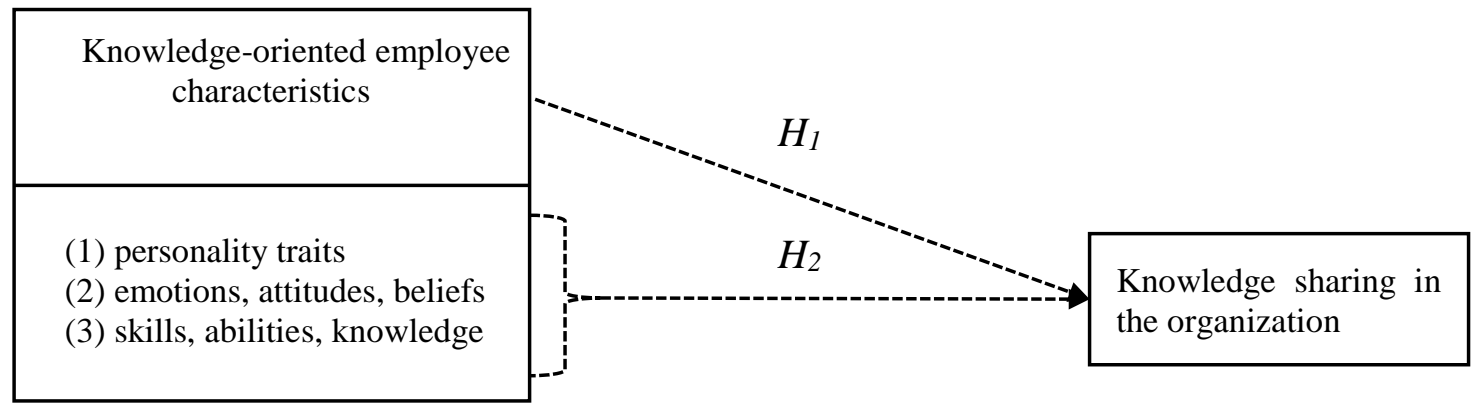




\section{METHODS}

The main aim of this study was to explore the dimensionality of employee characteristics that are mentioned in previous studies as increasing knowledge sharing behaviour in organizations. Quantitative research was carried out by opinion-based questionnaires. The questionnaires were anonymous, and participants were informed about the aim of the research project. Participation in the study was voluntary. The anonymity, privacy and confidentiality of individuals participating in the research were respected.

Several methods were employed to contact potential respondents, specifically sending emails with information about research to companies on the list of TOP $100 \mathrm{Czech}$ firms, to members of the biggest non-profit organization uniting HR managers, to the Regional Chamber of Commerce, then posting information about the survey on social networks Facebook and LinkedIn, and the web pages of our faculty, then cooperation with students and graduates, informing of the survey at a conference and a workshop, and a PR article in a journal for HR employees.

"Pen and paper" (146), as well as online (103) questionnaires, were used, but the content of the questionnaire was the same in both cases. Additionally, we have 81 questionnaires with answers only about knowledge sharing in organizations and they were added in the examination of statistical characteristics of this construct. Some questionnaires were filled incompletely and so they were not used in the analyses.

\subsection{Participants}

Participants' details are shown in Table I. According to previous consultations, the topic was supposed to be too delicate for many organizations. For this reason, the choice of companies based on their industry segment or their size was not restricted. Considering ways which were used to contact potential participants and the amount of gained fulfilled questionnaire, it can be 
said that the willingness of organizations and their employees to cooperate in the study was rather weak.

Table I. Profile of Participants

\subsection{Measures}

Knowledge sharing in the organization. The inventory described in Matošková, Macurová, and Tomancová (2018) was used. This questionnaire measures the perceived extent of knowledge sharing in the organization. It consists of 15 items, such as "Employees are informed of the turnover, revenue, economic and strategic issues in the company" or "During decision-making, e.g., about investment in a company, the proposals of employees are taken into consideration". Two types of this inventory were distributed - one version was meant for managers and HR employees; the second version was for others. The only difference between the versions was that the items for managers and HR employees contained the phrase "typical employee" whereas the items for others were formulated in "I-form." Participants evaluated the items according to their agreement with the given statement on a scale from 1 to $5(1=$ strongly disagree and $5=$ strongly agree). The scale of knowledge sharing used had high reliability, Cronbach's $\alpha=.86$.

Knowledge-oriented employee characteristics. This questionnaire finds out which employee characteristics mentioned in the literature as facilitating knowledge sharing are participant's own. The items were chosen based on the content analysis of the literature (Table II) and following team discussions. Especially databases Scopus and Web of Science was used to find literature. Similar items were omitted and 32 were left for an initial analysis. After five managers were asked to evaluate the comprehensibility and applicability of items. Based on their recommendations minor word changes were made. The results of the initial analysis were also a reason why 7 items were afterwards excluded. As no other study was found which would deal with the multidimensionality of knowledge-oriented employee characteristics, individual 
characteristics mentioned in previous studies as important were simply divided into three categories - 1) personality traits, 2) skills, abilities, knowledge, 3) emotions, attitudes, and beliefs. Participants assessed the items according to their agreement with the given statement on a scale from 1 to 5 ( $1=$ strongly disagree and $5=$ strongly agree $)$.

Table II. Literature overview for compiling the questionnaire of knowledge-oriented employee's characteristics

\subsection{Data analysis}

IBM ${ }^{\circledR}$ SPSS ${ }^{\circledR}$ Statistics software was used for statistical data analysis. A principal axis factor analysis of knowledge-oriented employee characteristics with oblique rotation (direct oblimin) was done. The Kaiser-Meyer-Olkin measure verified the sampling adequacy for the analysis, $\mathrm{KMO}=.91$, and all $\mathrm{KMO}$ values for individual items were greater than .80 , which is well above the acceptable limit of .5 (Field, 2013). Then its reliability analysis was conducted with the use of Cronbach's alpha and the basic characteristics of the variables employed in the survey were found. Finally, Pearson's correlations and regression analyses were used to examine the defined hypotheses.

\section{RESULTS}

Table III shows the basic characteristics of the items in the knowledge-oriented employee's characteristics inventory as well as the correlations with the extent of knowledge sharing in the organization. Feelings of safety, being respected, proud to be an employee and the belief in the reliability of information gain in the company are positively related to the extent of knowledge sharing.

Table III. Means and correlations with the extent of knowledge sharing of items of knowledgeoriented employee's characteristics and summary of factor analysis 
Four factors based on a principal axis factor analysis had eigenvalues over Kaiser's criterion of 1 and, in combination, explained $60.8 \%$ of the variance. Table III shows the factor loading after rotation. The items that cluster on the same factor suggest that factor 1 represents social and communication skills, factor 2 stands for positive work feelings, factor 3 competences (a mixture of skills and attitudes) for problem-solving, and factor 4 employee's self-efficacy. Social and communication skills are related to communication with others, managing emotions, and teamwork. Positive work feelings are associated with feelings of respect, safety, importance and usefulness of work, the pride of being a member of the organization, and trust in the reliability of the information given by other staff. Competences for problem-solving are about abilities to use technologies, apply techniques, and attitudes welcomed for solving problems, like a positive attitude to change. Self-efficacy means that an employee belief in his/her ability to give knowledge in the right way, the ability to manage time and personal development and owning knowledge and skills necessary for the job. All subscales of the questionnaire of knowledge-oriented employee's characteristics had good reliabilities and the total scale has high reliability too, Cronbach's $\alpha=.93$.

The basic characteristics of the examined variables are presented in Table IV. The means indicate that employee believes in their competencies and their positive work feelings predominate. As shown in Table IV, knowledge-oriented employee's characteristics were moderate-significantly related to the extent of knowledge sharing in the organization $(r=.366$ $95 \%$ BCI $[.168, .548], p<0.001)$. However, the relation between the extent of knowledge sharing in the organization and employee's competence for problem-solving was weak and unconvincing $(r=.199,95 \%$ BCI $[-.041, .398], p=.047)$. Also, the relation between the extent of knowledge sharing in the organization and employee's social and communication skills was only weak $(r=.266,95 \%$ BCI [.045, .477], $p=.007)$. Still, employee positive work feelings 
and his/her self-efficacy might matter because the identified correlations were moderate $(r>$ $0.4, p<0.001)$.

Table IV. Characteristics of the variables employed and Pearson's correlation coefficients among them

In the next step, regression analyses were done to predict the extent of knowledge sharing based on knowledge-oriented employee's characteristics. A significant regression equation was found $(F(1,100)=17.22, p<.001)$, with an $R^{2}$ of .15 . The extent of knowledge sharing is equal to $.0268+.459 *$ knowledge-oriented employee's characteristics. Except for competences for problem-solving, all dimensions of knowledge-oriented employee's characteristics also significantly predicted knowledge sharing in the organization (Figure 2).

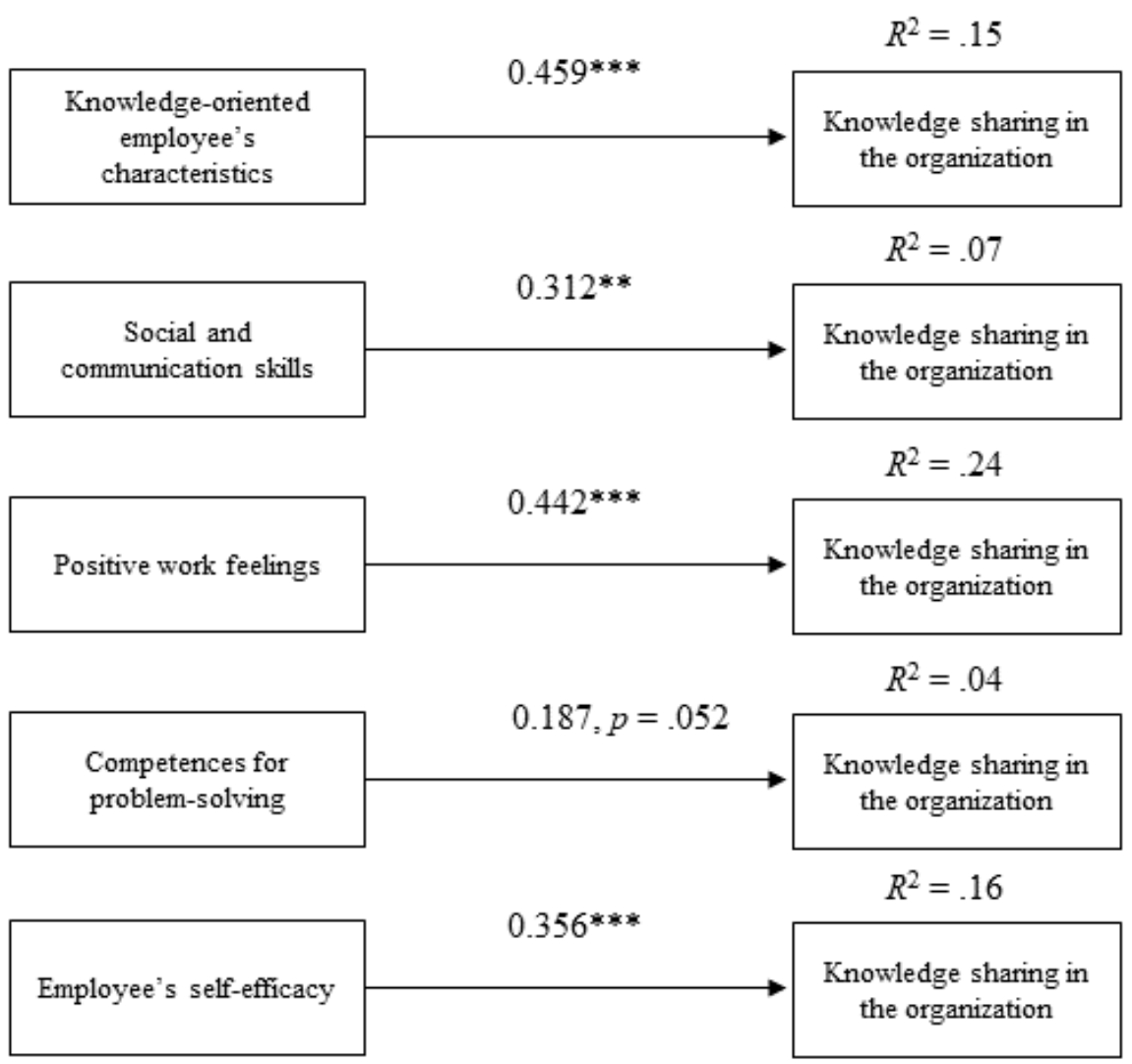

Note. $* * p<.01, * * * p<.001, N=102$

Fig. 2 - Simple regression analyses. Source: own research 
Similarly, results of a multiple linear regression indicated that there was a significant collective effect between four dimensions of knowledge-oriented employee's characteristics and the extent of knowledge sharing in the organization $\left(F(4,97)=9.97, p<.001, R^{2}=.29\right)$. The individual predictors were examined further and indicated that employee's positive work feelings $(\beta=.38$, BCa 95\% $[.119, .591], p=.001)$ and employee's self-efficacy $(\beta=.24$, BCa $95 \%[.020, .427], p=.04)$ were significant predictors in the regression model (Figure 3). If questionnaires used for evaluation of knowledge sharing in the organization based on the phrase "typical employee" were omitted, the results of the multiple linear regression were similar. However, employee's self-efficacy becomes insignificant $(\beta=.23$ [-.010, .464], $p=.06)$.

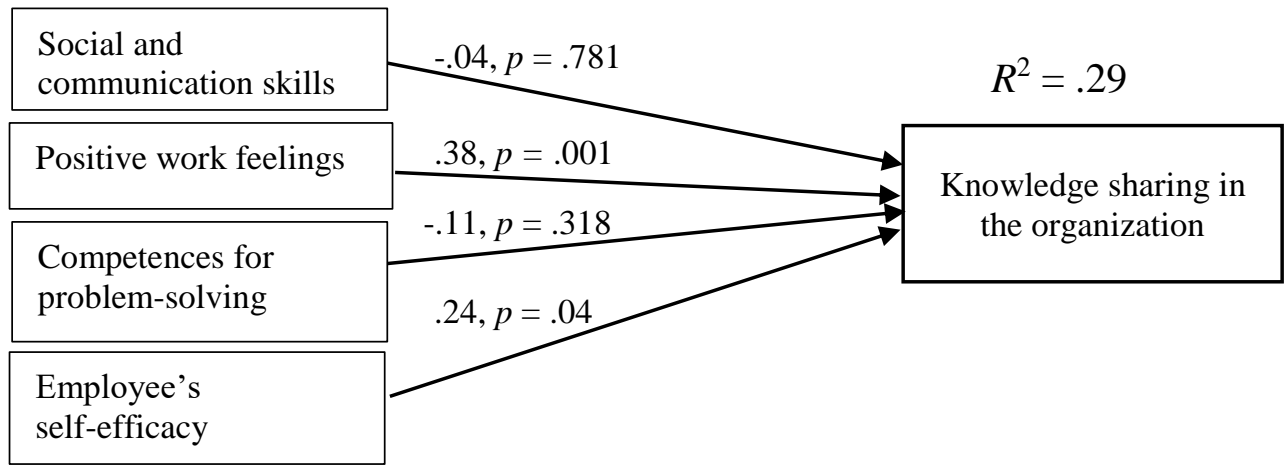

Note. $N=102$

Fig. 3 - A multiple regression analysis. Source: own research

\section{DISCUSSION}

Built on the existing research on the subject, this study attempted to enhance the understanding of the relationship between knowledge sharing and individual employee characteristics. This study aims to examine the dimensionality of employees' characteristics mentioned in previous studies as boosting knowledge sharing behaviour in organizations. For this purpose, a specific inventory for knowledge-oriented employee characteristics was suggested. Moreover, relations between identified specific dimensions and knowledge sharing 
were explored. Other studies, e.g. Esmaeelinezhad and Afrazeh (2018), Israilidis, Siachou, Cooke, and Lock (2015), have addressed other variables or only specific individual characteristics, such as adaptive behaviour (e. g. Hasgall and Shoham, 2008; Yi, 2009), ignorance (e.g. Israilidis et al., 2015), conscientiousness (e.g. Matzler et al., 2008), or outcome expectations (e.g. Hsu, Wu, et al., 2007).

The findings show some interesting insights. They provide strong support for the idea that specific individual employee characteristics increase spontaneous knowledge sharing behaviour. Thus, it has great importance to concentrate on knowledge-oriented candidates' qualities in the recruitment process and to further develop such qualities through employee training and development.

The factor analytic results offer a basis for future research. They suggest that individual employee characteristics mentioned in previous research about knowledge sharing behaviour can be divided into four categories: 1) social and communication skills, 2) positive work feelings, 3) competence for problem-solving, and 4) employee's self-efficacy. That means knowledge-oriented employee's characteristics are probably a multidimensional construct. They represent a mixture of features and qualities and includes thinking (about their competencies), feeling (about the job and the organization) and skills and all of them are reflected in employee behaviour.

Regarding identified dimensions of knowledge-oriented employee characteristics, selfefficacy and positive work feelings are not surprising. Previous research suggested that selfefficacy could be treated as a major factor of self-motivation in situations in which people face the challenge of combining and exchanging knowledge among individuals (Hsu, Ju, et al., 2007). Additionally, positive feelings improve helping behaviour, which is closely related to the willingness to share knowledge (Barnard and Pendock, 2013). 
As knowledge sharing between individuals require communication (Gumus, 2007; Hooff and Ridder, 2004), listening, persuading, teaching, learning, presenting, collaborating, and coordinating are supposed to be welcomed skills (Gumus, 2007). Also, empathy was found to affect eagerness and willingness to share knowledge (van den Hooff et al., 2012; Krok, 2013) because knowledge sharing is a form of helping behaviour and it decreases the knowledge source's discomfort when perceiving others in need (Xu and Cai, 2008). That might explain the third dimension of knowledge-oriented employee characteristics.

Considering the competence for problem-solving, it is closely related to people's ability to search, acquire information, and generate ideas and evaluate, select, and implement them (Carmeli et al., 2013). Thus, skills and attitudes related to this competence might enable employees to gain access to and exchange knowledge more effectively. That is why they might increase the eagerness and willingness to enter into the sharing process.

Identified dimensions of knowledge-oriented employee's characteristics have a positive collective effect on the extent of knowledge sharing in the organization. Only employee's positive work feelings and his/her self-efficacy might matter, as they significantly predicted the extent of knowledge sharing in this case. Thus, our results fail to provide support for the positive effect of employee's social and communication skills and employee's self-efficacy on knowledge sharing behaviour. However, comparing the results of simple regression analyses and the multiple regression analysis indicates that there might be some mediation effect between variables. It is possible that higher social and communication skills and competences for problem-solving increase employee's self-efficacy. This is supported for example by studies of Baile et al. (1999) or Kissane et al. (2012), which concludes that communication skills workshops increased employees' self-efficacy. People with higher social and communication skills might also have better positive work feelings. Similarly, Turetken et al. (2011) or (De 
Grip et al. (2009) found out employees with better communication skills are more satisfied with their job.

Generally, our findings imply that one way how to intensify knowledge sharing in an organization is to concentrate on human relationships. As the willingness to share knowledge is based on human relationships (Jackson, Hitt, et al., 2003), better staff relationships usually mean higher knowledge sharing. Another way to boost knowledge sharing might be to develop employees' self-efficacy. However, more data is needed to confirm the effect of employee's self-efficacy on knowledge sharing in the organization. Nevertheless, other studies support the importance of employee's self-efficacy for knowledge sharing (see e.g. Cabrera and Cabrera, 2005; Chen et al., 2012; Lin, 2007c).

\subsection{Managerial implications}

To accelerate knowledge sharing in the organization, staff relationships should be improved. Then the willingness for knowledge exchange would be not motivated only by self-interest, but by care for the community as well. This could be achieved via a selection process of candidates and concentration on their attitudes to people to avoid such employees who could damage cooperation and trust. Furthermore, it is possible to cultivate organizational culture. As previous research (e.g. García-Sánchez et al., 2017; Wang, 2016) suggested managers should build a work environment that promotes greater and more trusting ties among employees. Moulding such an environment will probably include frequent communication between management and employees (Lin, 2007b), some organizational activities for employees, such as get-together dinners, sporting contests, or sightseeing tours (Berman et al., 2002 as cited in Lin, 2007a), a supervisor's acceptance of an employee's autonomy and responsibility (Deci and Ryan 1985 as cited in Son, Cho, \& Kang, 2017).

As employee self-efficacy might be important, managers could try to increase employees' confidence in their abilities. Various mechanisms, such as internal and external training 
opportunities, intraorganizational virtual communities, mentoring systems, and crossfunctional teams for problem-solving, giving positive feedback from respected others can be used (see e.g. Cabrera and Cabrera, 2005; Chen and Huang, 2009; Luthans et al., 2008; Wang, 2016). Self-efficacy is also a quality which could be evaluated at the new employee's selection process. Additionally, Gu and Gu (2010) claim that managers should encourage employees and novices, among others, to respect each other and to grow and develop.

\subsection{Limitations of the study and perspectives for future research}

There are some limitations to this study that should be emphasized. The research design used in this study was cross-sectional. The character of the study was exploratory and so its primary goal was to identify an underlying set of latent constructs related with employee individual characteristics and not to test whether the data fit a hypothesized measurement model based on theory.

. Voluntary participation in this study might influence data quality and the questionnaire survey may suffer from response bias. Nevertheless, the anonymity and confidentiality of the volunteers were kept, which could decrease volunteer bias. Additionally, bootstrapping was used to achieve $95 \%$ confidence intervals, and they offer a more appropriate idea of the probable significance of correlation coefficients in the entire population. As a non-random sampling procedure was used to recruit respondents, there is still room for improvement regarding the generalizability of the research findings. Hence, future research could use a higher number of participants. Industrial and occupational differences could be considered in a new study as well. Another limitation of this study was that this study was conducted in a single country setting. Further research may consider collecting data from other countries so that a more comprehensive study can be made. As this study indicates possible mediation relations between examined variables, further research could bring more convincing evidence for such a statement. 


\section{CONCLUSIONS}

Despite limitations, this study has contributed to the understanding of the knowledgeoriented individual employee characteristics and their influence on the extent of knowledge sharing in organizations. A new inventory for knowledge-oriented employee characteristics was suggested and it shows high reliability. The findings show that specific individual employee characteristics increase spontaneous knowledge sharing behaviour. Moreover, a dimensionality of knowledge-oriented employee characteristics and relations between identified specific dimensions to knowledge sharing were examined. Four dimensions were suggested, but only two predicted the extent of knowledge sharing in the organization, namely employee's positive work feelings and employee self-efficacy. Future research is vital to confirm suggested dimensions and their relations to knowledge sharing. Additional research could extend the findings with characteristics that negatively influence knowledge sharing behaviour and their significance or examine possible mediation relations between identified dimensions of employees' knowledge-oriented characteristics. It might be also interesting to find out how identified knowledge-oriented employee individual characteristics are related to employee motivation. 


\section{Reference}

Afsar, B. (2016), “The impact of person-organization fit on innovative work behavior: The mediating effect of knowledge sharing behavior", International Journal of Health Care Quality Assurance, Vol. 29 No. 2, pp. 104-122.

Allameh, S.M., Abedini, A., Khazaei Pool, J. and Kazemi, A. (2012), “An Analysis of Factors Affecting Staffs Knowledge Sharing In the Central Library of the University of Isfahan Using the Extension of Theory of Reasoned Action", International Journal of Human Resource Studies, Vol. 2 No. 1, p. 158.

Amin, A., Hassan, M.F., Ariffin, M.Bt. and Rehman, M. (2009), “Theoretical framework of the effect of extrinsic rewards on individual's attitude towards knowledge sharing and the role of intrinsic attributes", Vol. 2, presented at the ICCTD 2009 - 2009 International Conference on Computer Technology and Development, pp. 240-243.

Audretsch, D.B., Belitski, M., Caiazza, R. and Lehmann, E.E. (2020), "Knowledge management and entrepreneurship", International Entrepreneurship and Management Journal, Vol. 16 No. 2, pp. 373-385.

Baile, W.F., Kudelka, A.P., Beale, E.A., Glober, G.A., Myers, E.G., Greisinger, A.J., Bast, R.C., et al. (1999), "Communication skills training in oncology”, Cancer, Vol. 86 No. 5, pp. 887-897.

Barnard, H. and Pendock, C. (2013), "To share or not to share: The role of affect in knowledge sharing by individuals in a diaspora", Journal of International Management, Vol. 19 No. 1, pp. 47-65.

van den Berg, J., Appel-Meulenbroek, R., Kemperman, A. and Sotthewes, M. (2020), “Knowledge workers' stated preferences for important characteristics of activity-based workspaces", Building Research \& Information, pp. 1-16.

Blau, P.M. (1964), Exchange and Power in Social Life, Transaction Publishers. 
Boateng, H., Dzandu, M.D. and Tang, Y. (2016), "Knowledge sharing among employees in Ghanaian Industries: The role of transformational leadership style and communal organizational culture”, Business Information Review, Vol. 33 No. 3, pp. 145-154.

Bock, G.W. and Kim, Y.-G. (2002), "Breaking the Myths of Rewards: An Exploratory Study of Attitudes About Knowledge Sharing”, Inf. Resour. Manage. J., Vol. 15 No. 2, pp. $14-21$.

Brčić, Ž.J. and Mihelič, K.K. (2015), "Knowledge sharing between different generations of employees: an example from Slovenia”, Economic Research-Ekonomska Istraživanja, Vol. 28 No. 1, pp. 853-867.

Brouwer, J. and Jansen, E. (2019), “Beyond grades: developing knowledge sharing in learning communities as a graduate attribute", Higher Education Research \& Development, Vol. 38 No. 2, pp. 219-234.

Cabrera, Á., Collins, W.C. and Salgado, J.F. (2006), "Determinants of individual engagement in knowledge sharing", The International Journal of Human Resource Management, Vol. 17 No. 2, pp. 245-264.

Cabrera, E.F. and Cabrera, A. (2005), "Fostering knowledge sharing through people management practices", International Journal of Human Resource Management, Vol. 16 No. 5, pp. $720-735$.

Carmeli, A., Gelbard, R. and Reiter-Palmon, R. (2013), "Leadership, Creative Problem-Solving Capacity, and Creative Performance: The Importance of Knowledge Sharing”, Human Resource Management, Vol. 52 No. 1, pp. 95-121.

Chen, C.-J. and Huang, J.-W. (2009), "Strategic human resource practices and innovation performance - The mediating role of knowledge management capacity", Journal of Business Research, Vol. 62 No. 1, pp. 104-114. 
Chen, G.-L., Ling, W.-Y., Yang, S.-C., Tang, S.-M. and Wu, W.-C. (2011), "Explicit Knowledge and Tacit Knowledge Sharing”, 2011 International Conference on Management and Service Science, presented at the 2011 International Conference on Management and Service Science (MASS 2011), IEEE, Wuhan, China, pp. 1-4.

Chen, S.-S., Chuang, Y.-W. and Chen, P.-Y. (2012), "Behavioral intention formation in knowledge sharing: Examining the roles of KMS quality, KMS self-efficacy, and organizational climate”, Knowledge-Based Systems, Vol. 31, pp. 106-118.

Chiang, H.-H., Han, T.-S. and Ju-Sung, C. (2011), “The relationship between high-commitment HRM and knowledge-sharing behavior and its mediators", International Journal of Manpower, Vol. 32 No. 5/6, pp. 604-622.

Chow, W.S. and Chan, L.S. (2008), "Social network, social trust and shared goals in organizational knowledge sharing", Information \& Management, Vol. 45 No. 7, pp. $458-465$.

Connelly, C.E. and Kelloway, E.K. (2003), "Predictors of employees' perceptions of knowledge sharing cultures”, Leadership \& Organization Development Journal, Vol. 24 No. 5, pp. 294-301.

Constant, D., Kiesler, S. and Sproull, L. (1994), "What's Mine Is Ours, or Is It? A Study of Attitudes about Information Sharing”, Information Systems Research, Vol. 5 No. 4, pp. $400-421$.

De Grip, A., Sieben, I. and Stevens, F. (2009), “Are more competent workers more satisfied?”, Labour, Vol. 23 No. 4, pp. 589-607.

Desouza, K.C. (2003), "Facilitating Tacit Knowledge Exchange", Communications of the ACM, Vol. 46 No. 6, pp. 85-88.

Dezdar, S. (2017), "Promoting knowledge sharing in academic environments using nonmonetary factors", Library Review, Vol. 66 No. 8-9, pp. 595-611. 
Donnelly, R. (2018), “Aligning knowledge sharing interventions with the promotion of firm success: The need for SHRM to balance tensions and challenges", Article in Press, Article in Press, , available at:https://doi.org/10.1016/j.jbusres.2018.02.007.

Ekaterine, G. and Natalia, K. (2017), "Impact of Time Management on Personal Development of Master's Degree Students", European Journal of Social Sciences Education and Research, Vol. 11 No. 2, p. 110.

Esmaeelinezhad, O. and Afrazeh, A. (2018), "Linking personality traits and individuals' knowledge management behavior", Aslib Journal of Information Management, Vol. 70 No. 3, pp. 234-251.

Field, A.P. (2013), Discovering Statistics Using IBM SPSS Statistics: And Sex and Drugs and Rock " $n$ ” Roll, 4th edition., Sage, Los Angeles.

Fong, C., Ooi, K., Tan, B., Lee, V. and Chong, A.Y. (2011), "HRM practices and knowledge sharing: an empirical study”, International Journal of Manpower, Vol. 32 No. 5/6, pp. $704-723$.

Gagné, M. (2009), “A model of knowledge-sharing motivation”, Human Resource Management, Vol. 48 No. 4, pp. 571-589.

García-Sánchez, P., Díaz-Díaz, N.L. and De, S.-P. (2017), "Social capital and knowledge sharing in academic research teams", Article in Press, Article in Press, , available at:https://doi.org/10.1177/0020852316689140.

Gu, Q. and Gu, Y. (2010), "Study on the construct of knowledge-sharing motivation”, presented at the 2010 International Conference on Management and Service Science, MASS 2010, available at:https://doi.org/10.1109/ICMSS.2010.5576982.

Gumus, M. (2007), “The Effect Of Communication On Knowledge Sharing In Organizations”, Journal of Knowledge Management Practice, Vol. 8 No. 2, available at: http://www.tlainc.com/articl133.htm (accessed 21 July 2020). 
Gupta, K.S. (2008), “A comparative analysis of knowledge sharing climate”, Knowledge and Process Management, Vol. 15 No. 3, pp. 186-195.

Hall, H. (2001), “Input-friendliness: motivating knowledge sharing across intranets", Journal of Information Science, Vol. 27 No. 3, pp. 139-146.

Hasgall, A. and Shoham, S. (2008), "Knowledge processes: from managing people to managing processes", Journal of Knowledge Management, Vol. 12 No. 1, pp. 51-62.

Hooff, B. van den and Ridder, J.A. de. (2004), "Knowledge sharing in context: the influence of organizational commitment, communication climate and $\mathrm{CMC}$ use on knowledge sharing", Journal of Knowledge Management, Vol. 8 No. 6, pp. 117-130.

van den Hooff, B., Schouten, A.P. and Simonovski, S. (2012), "What one feels and what one knows: The influence of emotions on attitudes and intentions towards knowledge sharing", Journal of Knowledge Management, Vol. 16 No. 1, pp. 148-158.

Hsiu-Fen Lin. (2007), “Knowledge sharing and firm innovation capability: an empirical study”, International Journal of Manpower, Vol. 28 No. 3/4, pp. 315-332.

Hsu, B.-F., Wu, W.-L. and Yeh, R.-S. (2007), "Personality Composition, Affective Tie and Knowledge Sharing: A Team Level Analysis", PICMET '07 - 2007 Portland International Conference on Management of Engineering \& Technology, presented at the PICMET '07 - 2007 Portland International Conference on Management of Engineering \& Technology, IEEE, Portland, OR, USA, pp. 2583-2592.

Hsu, M.-H., Ju, T.L., Yen, C.-H. and Chang, C.-M. (2007), “Knowledge sharing behavior in virtual communities: The relationship between trust, self-efficacy, and outcome expectations", International Journal of Human-Computer Studies, Vol. 65 No. 2, pp. $153-169$. 
Israilidis, J., Siachou, E., Cooke, L. and Lock, R. (2015), “Individual variables with an impact on knowledge sharing: the critical role of employees' ignorance”, Journal of Knowledge Management, Vol. 19 No. 6, pp. 1109-1123.

Jackson, S.E., DeNisi, A. and Hitt, M.A. (2003), Managing Knowledge for Sustained Competitive Advantage: Designing Strategies for Effective Human Resource Management, John Wiley \& Sons.

Jackson, S.E., Hitt, M.A. and DeNisi, A.S. (Eds.). (2003), Managing Knowledge for Sustained Competitive Advantage: Designing Strategies for Effective Human Resource Management, Jossey-Bass, San Francisco.

Jacobs, E. and Roodt, G. (2007), “The development of a knowledge sharing construct to predict turnover intentions", Aslib Proceedings: New Information Perspectives, Vol. 59 No. 3, pp. 229-248.

Jarvenpaa, S.L. and Staples, D.S. (2001), "Exploring Perceptions of Organizational Ownership of Information and Expertise”, Journal of Management Information Systems, Vol. 18 No. 1, pp. 151-183.

Kanaan, R., Masa'deh, R. and Gharibeh, A.H. (2013), “The impact of knowledge sharing enablers on knowledge sharing capability: an empirical study on Jordanian telecommunication firms”, European Scientific Journal, Vol. 9 No. 22, pp. 237-258.

Kankanhalli, A. and Tan, B.C. (2004), “A review of metrics for knowledge management systems and knowledge management initiatives", System Sciences, 2004. Proceedings of the 37th Annual Hawaii International Conference On, IEEE, pp. 8-pp.

Kim, Y.W. and Ko, J. (2014), "HR practices and knowledge sharing behavior: Focusing on the moderating effect of trust in supervisor", Public Personnel Management, Vol. 43 No. 4, pp. 586-607. 
King, W.R. (2007), “A research agenda for the relationships between culture and knowledge management”, Knowledge and Process Management, Vol. 14 No. 3, pp. 226-236.

Kissane, D.W., Bylund, C.L., Banerjee, S.C., Bialer, P.A., Levin, T.T., Maloney, E.K. and D’Agostino, T.A. (2012), “Communication Skills Training for Oncology Professionals”, Journal of Clinical Oncology, American Society of Clinical Oncology, Vol. 30 No. 11, pp. 1242-1247.

Krok, E. (2013), "Willingness to share knowledge compared with selected social psychology theories", Contemporary Economics, Vol. 7 No. 1, pp. 101-109.

Kubo, I., Saka, A. and Pam, S.L. (2001), "Behind the scenes of knowledge sharing in a Japanese bank.", Human Resource Development International, Vol. 4 No. 4, pp. 465-485.

Kuo, Y.-K., Kuo, T.-H. and Ho, L.-A. (2014), "Enabling innovative ability: knowledge sharing as a mediator", Industrial Management \& Data Systems, Vol. 114 No. 5, pp. 696-710.

Lasalewo, T., Subagyo, S., Hartono, B. and Yuniarto, H.A. (2016), “Communication constraints and motivations in the context of knowledge sharing: A Systematic Literature Review", Vol. 2016-December, presented at the IEEE International Conference on Industrial Engineering and Engineering Management, pp. 1804-1808.

Law, C.C. and Ngai, E.W. (2008), "An empirical study of the effects of knowledge sharing and learning behaviors on firm performance", Expert Systems with Applications, Vol. 34 No. 4, pp. 2342-2349.

Lazarus, R.S. (1993), "From Psychological Stress to the Emotions: A History of Changing Outlooks", Annual Review of Psychology, Vol. 44 No. 1, pp. 1-22.

Liebowitz, J. and Yan, C. (2004), "Knowledge Sharing Proficiencies: The Key to Knowledge Management”, in Holsapple, C.W. (Ed.), Handbook on Knowledge Management 1, Springer Berlin Heidelberg, Berlin, Heidelberg, pp. 409-424. 
Lin, C.-P. (2007a), "To share or not to share: Modeling tacit knowledge sharing, its mediators and antecedents", Journal of Business Ethics, Vol. 70 No. 4, pp. 411-428.

Lin, C.-P. (2007b), "To Share or Not to Share: Modeling Tacit Knowledge Sharing, Its Mediators and Antecedents", Journal of Business Ethics, Vol. 70 No. 4, pp. 411-428.

Lin, C.-P. and Joe, S.-W. (2012), "To Share or Not to Share: Assessing Knowledge Sharing, Interemployee Helping, and Their Antecedents Among Online Knowledge Workers”, Journal of Business Ethics, Vol. 108 No. 4, pp. 439-449.

Lin, H.-F. (2007c), "Effects of extrinsic and intrinsic motivation on employee knowledge sharing intentions", Journal of Information Science, Vol. 33 No. 2, pp. 135-149.

Luthans, F., Norman, S.M., Avolio, B.J. and Avey, J.B. (2008), "The mediating role of psychological capital in the supportive organizational climate: employee performance relationship", Journal of Organizational Behavior, Vol. 29 No. 2, pp. 219-238.

Matošková, J., Macurová, L. and Tomancová, L. (2018), “A link between knowledge sharing and managers' characteristics", Leadership and Organization Development Journal, Vol. 39 No. 8, pp. 1024-1036.

Matschke, C., Moskaliuk, J., Bokhorst, F., Schümmer, T. and Cress, U. (2014), "Motivational factors of information exchange in social information spaces", Computers in Human Behavior, Vol. 36, pp. 549-558.

Matzler, K., Renzl, B., Müller, J., Herting, S. and Mooradian, T.A. (2008), "Personality traits and knowledge sharing”, Journal of Economic Psychology, Vol. 29 No. 3, pp. 301-313.

McCrae, R. and Costa, P. (1997), "Personality Trait Structure as a Human Universal", The American Psychologist, Vol. 52, pp. 509-16.

McLure Wasko, M. and Faraj, S. (2000), “'It is what one does': why people participate and help others in electronic communities of practice", The Journal of Strategic Information Systems, Vol. 9 No. 2, pp. 155-173. 
Memon, S.B., Qureshi, J.A. and Jokhio, I.A. (2020), "The role of organizational culture in knowledge sharing and transfer in Pakistani banks: A qualitative study", Global Business and Organizational Excellence, Vol. 39 No. 3, pp. 45-54.

Mesmer-Magnus, J.R. and DeChurch, L.A. (2009), "Information Sharing and Team Performance: A Meta-Analysis", Journal of Applied Psychology, Vol. 94 No. 2, pp. $535-546$.

Moser, K.S. (2017), “The Influence of Feedback and Expert Status in Knowledge Sharing Dilemmas", Applied Psychology, Vol. 66 No. 4, pp. 674-709.

Obermayer-Kovács, N., Komlósi, E., Szenteleki, C. and Tóth, E.V. (2015), "Exploring Emotional Intelligence Trait Enablers for Knowledge Sharing: An Empirical Study”, International Journal of Synergy and Research, Vol. 4 No. 1, p. 7.

Peet, M. (2012), "Leadership transitions, tacit knowledge sharing and organizational generativity", Journal of Knowledge Management, Vol. 16 No. 1, pp. 45-60.

Peng, H. (2013), "Why and when do people hide knowledge?", Journal of Knowledge Management, Vol. 17 No. 3, pp. 398-415.

Rahman, M.S., Osman-Gani, A.M., Momen, M.A. and Islam, N. (2015), “Testing knowledge sharing effectiveness: Trust, motivation, leadership style, workplace spirituality and social network embedded model”, Management and Marketing, Vol. 10 No. 4, pp. 284303.

Ratajczak, M. (2016), "Knowledge of the concept of corporate social responsibility in agribusiness enterprises (based on the example of the SME sector in Malopolska)", Management, Vol. 20 No. 1, pp. 337-351.

Rehman, M., Mahmood, A.K., Salleh, R. and Amin, A. (2014), "Framework to increase knowledge sharing behavior among software engineers", Research Journal of Applied Sciences, Engineering and Technology, Vol. 7 No. 4, pp. 849-856. 
Riege, A. (2005), “Three-dozen knowledge-sharing barriers managers must consider”, Journal of Knowledge Management, Vol. 9 No. 3, pp. 18-35.

Rungsithong, R. and Meyer, K.E. (2020), “Trust and knowledge sharing in context: A study of international buyer-supplier relationships in Thailand", Industrial Marketing Management, Vol. 88, pp. 112-124.

Saide, Wei, H.-L., Subriadi, A.P., Okfalisa, Aini, N. and Rozanda, N.E. (2016), “Employees Characteristics in Knowledge Transfer and Performance", Computer Science \& Information Technology ( $C S \& I T$ ), presented at the Fifth International Conference on Advanced Computer Science and Information Technology, Academy \& Industry Research Collaboration Center (AIRCC), pp. 67-81.

Shi, G., Ma, Z., Feng, J., Zhu, F., Bai, X. and Gui, B. (2020), “The impact of knowledge transfer performance on the artificial intelligence industry innovation network: An empirical study of Chinese firms", edited by Xue, B.PLOS ONE, Vol. 15 No. 5, p. e0232658.

Smith, C. (2017), “An analysis of structural social capital and the individual's intention to share tacit knowledge using reasoned action theory", Journal of Applied Business Research, Vol. 33 No. 3, pp. 475-488.

Son, S.Y., Cho, D.H. and Kang, S. (2017), "The impact of close monitoring on creativity and knowledge sharing: The mediating role of leader-member exchange", Creativity and Innovation Management, Vol. 26 No. 3, pp. 256-265.

Srivastava, A., Bartol, K.M. and Locke, E.A. (2006), “Empowering Leadership in Management Teams: Effects on Knowledge Sharing, Efficacy, And Performance", Academy of Management Journal, Vol. 49 No. 6, pp. 1239-1251.

Stajkovic, A.D. and Luthans, F. (1998), "Self-efficacy and work-related performance: A metaanalysis.", Psychological Bulletin, Vol. 124 No. 2, pp. 240-261. 
Sunardi, O. (2017), "Linking human capital and enterprise sustainability in Indonesian medium-sized food manufacturing enterprises: The role of informal knowledge sharing practice", Vol. 277, presented at the IOP Conference Series: Materials Science and Engineering, available at:https://doi.org/10.1088/1757-899X/277/1/012040.

Tamta, V. and Rao, M.K. (2017), "Linking Emotional Intelligence to Knowledge Sharing Behaviour: Organizational Justice and Work Engagement as Mediators", Global Business Review, Vol. 18 No. 6, pp. 1580-1596.

Teng, J.T.C. and Song, S. (2011), “An exploratory examination of knowledge- sharing behaviors: Solicited and voluntary", Journal of Knowledge Management, Vol. 15 No. 1, pp. 104-117.

Turetken, O., Jain, A., Quesenberry, B. and Ngwenyama, O. (2011), “An Empirical Investigation of the Impact of Individual and Work Characteristics on Telecommuting Success", IEEE Transactions on Professional Communication, presented at the IEEE Transactions on Professional Communication, Vol. 54 No. 1, pp. 56-67.

Ulhøi, J.P. and Stjernholm Madsen, A. (2005), “Technology innovation, human resources and dysfunctional integration”, International Journal of Manpower, Vol. 26 No. 6, pp. 488501.

Wahyudi, S., Udin, U., Yuniawan, A. and Rahardja, E. (2019), "Person-organization fit, knowledge sharing behaviour, and innovative work behaviour: A self-determination perspective", International Journal of Innovation, Creativity and Change, Vol. 4 No. 4, pp. 145-161.

Wang, T.-I., Su, C.-Y. and Hsieh, T.-C. (2011), “Accumulating and visualising tacit knowledge of teachers on educational assessments", Computers \& Education, Vol. 57 No. 4, pp. 2212-2223. 
Wang, W. (2016), "Examining the influence of the social cognitive factors and relative autonomous motivations on employees' knowledge sharing behaviors", Decision Sciences, Vol. 47 No. 3, pp. 404-436.

Wasko, M.M. and Faraj, S. (2005), "Why Should I Share? Examining Social Capital and Knowledge Contribution in Electronic Networks of Practice”, MIS Quarterly, Vol. 29 No. 1, pp. 35-57.

Wilson, T.D. (2010), "Information sharing: An exploration of the literature and some propositions", Information Research, Vol. 15 No. 4.

Wright, P.M., Dunford, B.B. and Snell, S.A. (2001), "Human resources and the resource based view of the firm", Journal of Management, Vol. 27 No. 6, pp. 701-721.

Wu, L.-W. and Lin, J.-R. (2013), "Knowledge sharing and knowledge effectiveness: learning orientation and co-production in the contingency model of tacit knowledge", Journal of Business \& Industrial Marketing, Vol. 28 No. 8, pp. 672-686.

Wu, W.-L. (2013), "To share knowledge or not: Dependence on knowledge-sharing satisfaction”, Social Behavior and Personality, Vol. 41 No. 1, pp. 47-58.

Wuryaningrat, N.F., Kindangen, P., Sendouw, G. and Lumanouw, B. (2019), "The role of person job fit and person organization fit on the development of innovation capabilities at indonesia creative industry", International Journal of Engineering and Advanced Technology, Vol. 8 No. 5C, pp. 80-85.

$\mathrm{Xu}, \mathrm{Y}$. and Cai, S. (2008), "Voluntary knowledge sharing in organizations", presented at the PACIS 2008 - 12th Pacific Asia Conference on Information Systems: Leveraging ICT for Resilient Organizations and Sustainable Growth in the Asia Pacific Region.

Yi, J. (2009), “A measure of knowledge sharing behavior: scale development and validation”, Knowledge Management Research \& Practice, Vol. 7 No. 1, pp. 65-81. 
Yoong, P. (Ed.). (2010), Leadership in the Digital Enterprise: Issues and Challenges, IGI Global, available at:https://doi.org/10.4018/978-1-60566-958-8.

Zack, M.H. (2003), "Rethinking the knowledge-based organization”, MIT Sloan Management Review, Vol. 44 No. 4, pp. 67-71.

Zhang, J., Scardamalia, M., Reeve, R. and Messina, R. (2009), "Designs for Collective Cognitive Responsibility in Knowledge-Building Communities", Journal of the Learning Sciences, Vol. 18 No. 1, pp. 7-44.

Zheng, T. (2017), “A Literature Review on Knowledge Sharing”, Open Journal of Social Sciences, Vol. 05, p. 51. 
Table I. Profile of Participants

\begin{tabular}{|c|c|c|c|c|c|}
\hline \multirow[b]{2}{*}{ Measure } & \multirow[b]{2}{*}{ Items } & \multicolumn{2}{|c|}{$\begin{array}{c}\text { Knowledge-oriented } \\
\text { employee's } \\
\text { characteristics } \\
\end{array}$} & \multicolumn{2}{|c|}{$\begin{array}{c}\text { The sample used for } \\
\text { correlation and regression } \\
\text { analyses }\end{array}$} \\
\hline & & $\begin{array}{c}\text { \# of } \\
\text { response }\end{array}$ & $\%$ & $\begin{array}{c}\text { \# of } \\
\text { response }\end{array}$ & $\%$ \\
\hline \multirow[t]{6}{*}{ Industry Type } & Manufacturing & 155 & 67.4 & 37 & 36.3 \\
\hline & Construction & 52 & 22.6 & 42 & 41.2 \\
\hline & Education & 20 & 8.7 & 20 & 19.6 \\
\hline & Others & 3 & 1.3 & 3 & 2.9 \\
\hline & Missing & & & & \\
\hline & Total & 230 & 100 & 102 & 100 \\
\hline \multirow[t]{3}{*}{ Gender } & Male & 55 & 23.9 & 55 & 53.9 \\
\hline & Female & 47 & 20.4 & 47 & 46.1 \\
\hline & Missing & 128 & 55.7 & & \\
\hline \multirow[t]{5}{*}{ Age } & Less than 25 & 4 & 1.7 & 4 & 3.9 \\
\hline & $25-40$ & 52 & 22.6 & 52 & 51 \\
\hline & $41-60$ & 43 & 18.7 & 43 & 42.2 \\
\hline & More than 60 & 3 & 1.3 & 3 & 2.9 \\
\hline & Missing & 128 & 55.7 & & \\
\hline \multirow[t]{3}{*}{ Work position } & Manager & 31 & 13.5 & 23 & 22.5 \\
\hline & Others & 154 & 66.9 & 78 & 76.5 \\
\hline & Missing & 45 & 19.5 & 1 & 1.0 \\
\hline \multirow[t]{4}{*}{ Education } & $\begin{array}{l}\text { Apprentice } \\
\text { school }\end{array}$ & 23 & 10.0 & 23 & 22.5 \\
\hline & Secondary & 33 & 14.3 & 33 & 32.4 \\
\hline & University & 46 & 20.0 & 46 & 45.1 \\
\hline & Missing & 128 & 55.7 & & \\
\hline \multicolumn{6}{|c|}{$\begin{array}{lcc}\text { Number } & \text { of } & \text { years } \\
\text { working } & \text { for } & \text { the }\end{array}$} \\
\hline current organization & Less than 2 & 24 & 10.4 & 24 & 23.5 \\
\hline & $2-5$ & 23 & 10.0 & 23 & 22.5 \\
\hline & $6-10$ & 20 & 8.7 & 20 & 19.6 \\
\hline & More than 10 & 35 & 15.2 & 35 & 34.3 \\
\hline & Missing & 128 & 55.7 & & \\
\hline $\begin{array}{l}\text { Type of the } \\
\text { questionnaire used fo } \\
\text { knowledge sharing } \\
\text { assessment }\end{array}$ & $\begin{array}{l}\text { "Typical } \\
\text { employee" } \\
\text { "I" }\end{array}$ & & & $\begin{array}{l}31 \\
71\end{array}$ & $\begin{array}{l}30 \\
70 \\
\end{array}$ \\
\hline
\end{tabular}


Table II. Literature overview for compiling the questionnaire of knowledge-oriented employee's characteristics

Item Author(s)

\section{EMOTIONS, ATTITUDES \& BELIEFS}

1. I like my work.

2. I feel that my work is important and useful.

3. I feel that I am respected in the company.

4. I'm not afraid of any misuse of my information or knowledge in the company.

5. I feel safe in the company.

6. I am ready to use information and communication technologies (computer, mobile telephone, Internet, etc.) in my work.

7. I am open to change; I do not resist it.

8. I am ready to take responsibility for my decisions.

9. I am proud to be an employee of our company.

10. I am willing to communicate with my co-workers.

11. I believe that people in the company provide me with reliable information.

12. I am ready to learn and be educated (e.g. (Cabrera and Cabrera, 2005) in development courses, by reading books).

13. I respect the other team members.
(Chen et al., 2011; Hsiu-Fen Lin, 2007)

(Tamta and Rao, 2017)

(Chow and Chan, 2008; Israilidis et al., 2015)

(Hall, 2001; Hooff and Ridder, 2004)

(Cabrera and Cabrera, 2005)

(Kankanhalli and Tan, 2004; Stajkovic and Luthans, 1998)

(Obermayer-Kovács et al., 2015; Yoong, 2010)

(Zhang et al., 2009)

(Bock and Kim, 2002; Kanaan et al., 2013)

(Hooff and Ridder, 2004; Ratajczak, 2016)

(Ratajczak, 2016; Yi, 2009)

(Wang, 2016)

\section{SKILLS, ABILITIES AND KNOWLEDGE}

14. I can provide my knowledge to others in an appropriate manner.

(Moser, 2017; Sunardi, 2017; Wasko and Faraj, 2005)

15. I can manage my time and further development.

(Ekaterine and Natalia, 2017)

16. I have the professional knowledge and skills that I need in my work.

(Constant et al., 1994)

17. I can manage my emotions.

(Lazarus, 1993; Wu, 2013) 
18. I can empathize with the emotions and needs of others.

19. I can communicate with people.

20. I can use basic information and communication technologies (computer, mobile telephone, Internet).

21. I manage techniques and tools for solving problems (e.g. for analysis, decisions).

22. I can work in a team.
(Lazarus, 1993; Wu and Lin, 2013)

(Cabrera et al., 2006)

(Cabrera et al., 2006; Cabrera and Cabrera, 2005; Dezdar, 2017; Ulhøi and Stjernholm Madsen, 2005)

(Dezdar, 2017; Gu and Gu, 2010; Wasko and Faraj, 2005)

(Moser, 2017; Peng, 2013)

\section{TRAITS}

23. I am friendly to my co-workers.

(Wasko and Faraj, 2005)

24. I am patient when discussing things with (Hooff and Ridder, 2004) my co-workers.

25 . I keep the promises I gave to my co(Allameh et al., 2012) workers. 
Table III. Means and correlations with the extent of knowledge sharing of items of knowledge-oriented employee's characteristics and summary of factor analysis

\begin{tabular}{|c|c|c|c|c|c|c|}
\hline Item & $M$ & $\begin{array}{c}r \text { with } \\
\text { KS }\end{array}$ & $\begin{array}{c}\text { Social and } \\
\text { communication } \\
\text { skills }\end{array}$ & $\begin{array}{l}\text { Rotated } \\
\text { Positive } \\
\text { work } \\
\text { feelings }\end{array}$ & $\begin{array}{l}\text { Factor Loadings } \\
\text { Competences for } \\
\text { problem-solving }\end{array}$ & $\begin{array}{l}\text { Employee's } \\
\text { self-efficacy }\end{array}$ \\
\hline I like my work. & 4.20 & .113 & -.132 & .480 & -.433 & -.221 \\
\hline I feel that my work is important and useful. & 4.19 & $.161 *$ & -.163 & .515 & -.329 & -.239 \\
\hline I feel that I am respected in the company. & 3.55 & $.228 * *$ & -.100 & .805 & .055 & -.017 \\
\hline $\begin{array}{l}\text { I'm not afraid of any misuse of my information or knowledge in the } \\
\text { company. }\end{array}$ & 3.92 & $.146^{*}$ & .082 & .625 & -.029 & .090 \\
\hline I feel safe in the company. & 4.09 & $.314 * *$ & .085 & .766 & .070 & -.017 \\
\hline I can provide my knowledge to others in an appropriate manner. & 4.03 & $.137 *$ & .342 & .025 & -.113 & -.416 \\
\hline I can manage my time and further development. & 3.88 & $.176^{*}$ & .205 & .122 & .038 & -.666 \\
\hline I have the professional knowledge and skills that I need in my work. & 4.02 & $.154 *$ & .191 & .062 & -.162 & -.421 \\
\hline I can manage my emotions. & 3.79 & -.004 & .462 & .016 & .047 & -.142 \\
\hline I can empathize with the emotions and needs of others. & 3.92 & -.061 & .549 & .061 & -.097 & .067 \\
\hline I can communicate with people. & 4.17 & .088 & .539 & .002 & -.099 & -.270 \\
\hline $\begin{array}{l}\text { I can use basic information and communication technologies (computer, } \\
\text { mobile telephone, Internet). }\end{array}$ & 4.55 & .039 & .145 & .009 & -.667 & .023 \\
\hline $\begin{array}{l}\text { I manage techniques and tools for solving problems (e.g. for analysis, } \\
\text { decisions). }\end{array}$ & 3.87 & .002 & -.042 & -.019 & -.486 & -.248 \\
\hline I can work in a team. & 4.39 & .106 & .476 & .067 & -.213 & -.135 \\
\hline I am friendly to my co-workers. & 4.27 & .064 & .730 & .021 & -.074 & -.005 \\
\hline I am patient when discussing things with my co-workers. & 4.07 & .087 & .796 & .016 & .049 & -.033 \\
\hline I keep the promises I gave to my co-workers. & 4.46 & .08 & .592 & -.068 & -.153 & -.208 \\
\hline I respect the other team members. & 4.45 & .116 & .483 & .067 & -.362 & -.023 \\
\hline
\end{tabular}


I am ready to use information and communication technologies (computer, mobile telephone, Internet, etc.) in my work.

I am open to change; I do not resist it.

I am ready to take responsibility for my decisions.

I am proud to be an employee of our company.

I am willing to communicate with my co-workers.

I believe that people in the company provide me with reliable

information.

I am ready to learn and be educated (e.g. in development courses, by reading books).

\section{Eigenvalues}

$4.59 \quad .08$

$4.17-.016$

$4.45 \quad .067$

$4.00 .250 * *$

$4.42 \quad .081$

$3.67 .241 * *$

$4.21 \quad .012$

$\%$ of variance

$\alpha$

Notes. $\mathrm{KS}=$ knowledge sharing. $* \mathrm{p}<.05, * * \mathrm{p}<.01$. Factor loadings over .40 appear in bold.
.010

.102

$-.057$

.012

.047

$-.051$

$-.044$

1.06

4.22

.76 
Table IV. Characteristics of the variables employed and Pearson's correlation coefficients among them

\begin{tabular}{|c|c|c|c|c|c|c|c|c|c|}
\hline & $N$ & $M$ & $S D$ & 1 & 2 & 3 & 4 & 5 & 6 \\
\hline 1 Knowledge sharing in the organization & 315 & 6260 & .1355 & 1 & $\begin{array}{c}.266 * * \\
{[.045, .477]}\end{array}$ & $\begin{array}{l}.519 * * * \\
{[.324, .670]}\end{array}$ & $\begin{array}{c}.199 * \\
{[-.041, .398]}\end{array}$ & $\begin{array}{c}.413 * * * \\
{[.214, .587]}\end{array}$ & $\begin{array}{c}.366 * * * \\
{[.168, .548]}\end{array}$ \\
\hline 2 Employee's social and communication skills & 230 & .8435 & .1205 & 100 & 1 & $\begin{array}{c}.430 * * * \\
{[.295, .558]}\end{array}$ & $\begin{array}{l}.724 * * * \\
{[.622, .805]}\end{array}$ & $\begin{array}{c}.680 * * * \\
{[.810, .905]}\end{array}$ & $\begin{array}{c}.864 * * * \\
{[.810, .905]}\end{array}$ \\
\hline 3 Employee's positive work feelings & 230 & .7889 & .1480 & 100 & 229 & 1 & $\begin{array}{c}.448 * * * \\
{[.327, .562]}\end{array}$ & $\begin{array}{c}.478 * * * \\
{[.379, .580]}\end{array}$ & $\begin{array}{c}.726 * * * \\
{[.660, .788]}\end{array}$ \\
\hline $\begin{array}{l}4 \text { Employee's competence for problem- } \\
\text { solving }\end{array}$ & 230 & .8604 & .1265 & 100 & 229 & 229 & 1 & $\begin{array}{c}.605 * * * \\
{[.488, .707]}\end{array}$ & $\begin{array}{c}.859 * * * \\
{[.807, .900]}\end{array}$ \\
\hline 5 Employee's self-efficacy & 229 & .7949 & .1456 & 100 & 229 & 229 & 229 & 1 & $\begin{array}{c}.795 * * * \\
{[.734, .847]}\end{array}$ \\
\hline $\begin{array}{l}6 \text { Knowledge-oriented employee's } \\
\text { characteristics }\end{array}$ & 230 & .8247 & .1102 & 95 & 229 & 229 & 229 & 229 & 1 \\
\hline
\end{tabular}

Notes. $* \mathrm{p}<.05, * * \mathrm{p}<.01, * * * \mathrm{p}<.001$. Pearson's correlation coefficients were calculated on different research samples $(\mathrm{N}=100$ or 229$)$, they are marked. $95 \%$ bootstrap confidence intervals related to Pearson's correlation coefficients are in brackets and are based on 1000 bootstrap samples. 